\title{
MyPyramid Plan for Daily Food and Calorie Intake
}

\author{
Glenda L. Warren
}

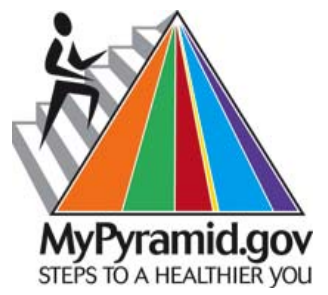

MyPyramid is your guide to a healthy eating plan and an active lifestyle. The MyPyramid plan:

- Emphasizes fruits, vegetables, whole grains, and fat-free or low-fat milk and milk products.

- Includes lean meats, poultry, fish, beans, eggs, and nuts.

- Is low in saturated fats, trans fats, cholesterol, salt (sodium), and added sugars.

- Recommends daily physical activity for 30 to 60 minutes every day.

- Explains that oils are not a food group, but some are needed for your good health.

\begin{tabular}{|c|c|c|c|c|c|c|c|}
\hline CALORIES & GRAINS & VEGETABLES & FRUITS & $\begin{array}{l}\text { O } \\
\text { I } \\
\text { L } \\
\text { S }\end{array}$ & MILK & $\begin{array}{l}\text { MEAT \& } \\
\text { BEANS }\end{array}$ & $\begin{array}{l}\text { Discretionary } \\
\text { Calorie } \\
\text { Allowance }\end{array}$ \\
\hline 1,000 & $3 \mathrm{oz}$ & 1 cup & 1 cup & 3 & 2 cups & $2 \mathrm{oz}$ & 165 \\
\hline 1,200 & $4 \mathrm{oz}$ & 1.5 cups & 1 cup & 4 & 2 cups & $3 \mathrm{oz}$ & 171 \\
\hline 1,400 & $5 \mathrm{oz}$ & 1.5 cups & 1.5 cups & 4 & 2 cups & $4 \mathrm{oz}$ & 171 \\
\hline 1,600 & $5 \mathrm{oz}$ & 2 cups & 1.5 cups & 5 & 3 cups & $5 \mathrm{oz}$ & 132 \\
\hline 1,800 & $6 \mathrm{oz}$ & 2.5 cups & 1.5 cups & 5 & 3 cups & $5 \mathrm{oz}$ & 195 \\
\hline 2,000 & $6 \mathrm{oz}$ & 2.5 cups & 2 cups & 6 & 3 cups & $5.5 \mathrm{oz}$ & 267 \\
\hline 2,200 & $7 \mathrm{oz}$ & 3 cups & 2 cups & 6 & 3 cups & $6 \mathrm{oz}$ & 290 \\
\hline 2,400 & $8 \mathrm{oz}$ & 3 cups & 2 cups & 7 & 3 cups & $6.5 \mathrm{oz}$ & 362 \\
\hline 2,600 & $9 \mathrm{oz}$ & 3.5 cups & 2 cups & 8 & 3 cups & $6.5 \mathrm{oz}$ & 410 \\
\hline 2,800 & $10 \mathrm{oz}$ & 3.5 cups & 2.5 cups & 8 & 3 cups & $7 \mathrm{oz}$ & 426 \\
\hline 3,000 & $10 \mathrm{oz}$ & 4 cups & 2.5 cups & 10 & 3 cups & $7 \mathrm{oz}$ & 512 \\
\hline 3,200 & $10 \mathrm{oz}$ & 4 cups & 2.5 cups & 11 & 3 cups & $7 \mathrm{oz}$ & 648 \\
\hline
\end{tabular}

*Numbers represent teaspoons of oils at your calorie level.

Limit the amount of calories used for fat and sugar to the amount in the discretionary calorie allowance for your calorie level. Remember, total recommended daily amounts are based on serving the foods without any added fats or sugar.

1. This document is FCS8800, one of a series of the Department of Family, Youth and Community Sciences, Florida Cooperative Extension Service, Institute of Food and Agricultural Sciences, University of Florida. Adapted from CNP-XX, "MyPyramid Food Intake Pattern Calorie Levels," United States Department of Agriculture, Center for Nutrition Policy and Promotion, April 2005. First published: December 2007. Please visit the EDIS Web site at http://edis.ifas.ufl.edu

2. Glenda L. Warren, M.S., R.D., CFCS, Associate Professor, Extension Nutritionist - EFNEP, Department of Family, Youth and Community Sciences, Cooperative Extension Service, Institute of Food and Agricultural Sciences, University of Florida, Gainesville, FL 32611.

The Institute of Food and Agricultural Sciences (IFAS) is an Equal Opportunity Institution authorized to provide research, educational information and other services only to individuals and institutions that function with non-discrimination with respect to race, creed, color, religion, age, disability, sex, sexual orientation, marital status, national origin, political opinions or affiliations. For more information on obtaining other extension publications, contact your county Cooperative Extension service. U.S. Department of Agriculture, Cooperative Extension Service, University of Florida, IFAS, Florida A. \& M. University Cooperative Extension Program, and Boards of County Commissioners Cooperating. Larry Arrington, Dean. 
Find the calorie level that is right for your gender, activity level, and age.**

1. First, choose the column for your gender.

2. Next, choose your activity level.

3. Then, find your age and the calorie level that matches your physical activity.

\begin{tabular}{|c|c|c|c|c|c|c|c|}
\hline \multirow[b]{2}{*}{ Activity Level } & \multicolumn{3}{|c|}{ MALES } & \multirow[b]{2}{*}{ Activity Level } & \multicolumn{3}{|c|}{ FEMALES } \\
\hline & Sedentary* & Mod active* & Active* $^{*}$ & & Sedentary* & Mod active* & Active* $^{\star}$ \\
\hline AGE & & & & AGE & & & \\
\hline 2 & 1000 & 1000 & 1000 & 2 & 1000 & 1000 & 1000 \\
\hline 3 & 1000 & 1400 & 1400 & 3 & 1000 & 1200 & 1400 \\
\hline 4 & 1200 & 1400 & 1600 & 4 & 1200 & 1400 & 1400 \\
\hline 5 & 1200 & 1400 & 1600 & 5 & 1200 & 1400 & 1600 \\
\hline 6 & 1400 & 1600 & 1800 & 6 & 1200 & 1400 & 1600 \\
\hline 7 & 1400 & 1600 & 1800 & 7 & 1200 & 1600 & 1800 \\
\hline 8 & 1400 & 1600 & 2000 & 8 & 1400 & 1600 & 1800 \\
\hline 9 & 1600 & 1800 & 2000 & 9 & 1400 & 1600 & 1800 \\
\hline 10 & 1600 & 1800 & 2200 & 10 & 1400 & 1800 & 2000 \\
\hline 11 & 1800 & 2000 & 2200 & 11 & 1600 & 1800 & 2000 \\
\hline 12 & 1800 & 2200 & 2400 & 12 & 1600 & 2000 & 2200 \\
\hline 13 & 2000 & 2200 & 2600 & 13 & 1600 & 2000 & 2200 \\
\hline 14 & 2000 & 2400 & 2800 & 14 & 1800 & 2000 & 2400 \\
\hline 15 & 2200 & 2600 & 3000 & 15 & 1800 & 2000 & 2400 \\
\hline 16 & 2400 & 2800 & 3200 & 16 & 1800 & 2000 & 2400 \\
\hline 17 & 2400 & 2800 & 3200 & 17 & 1800 & 2000 & 2400 \\
\hline 18 & 2400 & 2800 & 3200 & 18 & 1800 & 2000 & 2400 \\
\hline $19-20$ & 2600 & 2800 & 3000 & $19-20$ & 2000 & 2200 & 2400 \\
\hline $21-25$ & 2400 & 2800 & 3000 & $21-25$ & 2000 & 2200 & 2400 \\
\hline $26-30$ & 2400 & 2600 & 3000 & $26-30$ & 1800 & 2000 & 2400 \\
\hline $31-35$ & 2400 & 2600 & 3000 & $31-35$ & 1800 & 2000 & 2200 \\
\hline $36-40$ & 2400 & 2600 & 2800 & $36-40$ & 1800 & 2000 & 2200 \\
\hline 41-45 & 2200 & 2600 & 2800 & 41-45 & 1800 & 2000 & 2200 \\
\hline $46-50$ & 2200 & 2400 & 2800 & $45-50$ & 1800 & 2000 & 2200 \\
\hline $51-55$ & 2200 & 2400 & 2800 & $51-55$ & 1600 & 1800 & 2200 \\
\hline $56-60$ & 2200 & 2400 & 2600 & $56-60$ & 1600 & 1800 & 2200 \\
\hline 61-65 & 2000 & 2400 & 2600 & 61-65 & 1600 & 1800 & 2000 \\
\hline $66-70$ & 2000 & 2200 & 2600 & $66-70$ & 1600 & 1800 & 2000 \\
\hline $71-75$ & 2000 & 2200 & 2600 & $71-75$ & 1600 & 1800 & 2000 \\
\hline 76 and up & 2000 & 2200 & 2400 & 76 and up & 1600 & 1800 & 2000 \\
\hline
\end{tabular}

${ }^{*}$ Calorie levels are based on the Estimated Energy Requirements (EER) and activity levels from the Institute of Medicine Dietary Reference Intakes Macronutrients Report, 2002.

SEDENTARY = less than 30 minutes a day of moderate physical activity, in addition to daily activities.

MOD. ACTIVE = at least 30 minutes and up to 60 minutes a day of moderate physical activity, in addition to daily activities.

ACTIVE $=60$ or minutes a day of moderate physical activity, in addition to daily activities.

**You can also find calorie levels for your family members. 